Andrzej Wieloński, Katarzyna Szmigiel

Uniwersytet Warszawski

\title{
Regionalne strategie innowacji jako czynnik aktywizacji polskiej przestrzeni przemysłowej
}

\author{
IDEA REGIONALNYCH STRATEGII INNOWACJI
}

Regionalne strategie innowacji są narzędziem budowania regionalnego systemu innowacji. Są narzędziem specjalizującym politykę samorządu regionalnego w stronę rozwoju sektora przedsiębiorstw. Regionalne systemy innowacji to środowisko regionalne zbudowane w sposób sprzyjający tworzeniu, transferowi i wykorzystywaniu wiedzy służącej rozwojowi społeczno-gospodarczemu. Cechą charakterystyczną regionalnych systemów innowacji jest ich zakorzenienie w środowisku regionalnym. We wszystkich dokumentach Unii Europejskiej związanych z analizą procesu budowania RSI podkreśla się, że jest to działanie wpisujące się w cele strategii lizbońskiej.

\section{CEL RegionalnyCH SYSTEMÓW INNOWACJI}

Cel ten to rozwój społeczno-gospodarczy regionu poprzez budowę gospodarki opartej na wiedzy społeczeństwa informacyjnego. Ważnym elementem realizacji tego celu jest budowanie regionalnego konsensusu na rzecz podnoszenia w regionie aktywności, współpracy i otwartości. Przy czym, nie są ściśle określone instytucje, których dotyczyć mają te działania. Może być to każda instytucja w regionie, której działania przyczyniają się do rozwoju społeczno-gospodarczego w tym konkretnym regionie. Działania tej instytucji muszą wpisywać się w środowisko gospodarcze regionu. Powinny być częścią systemu opartego na dziedzinie lub dziedzinach stanowiących specjalność regionu.

Tym samym najważniejszym celem regionalnych strategii innowacji nie jest implementowanie nowych, uważanych za najnowocześniejsze branż działalności gospodarczej, ale rozwijanie, dostosowywanie do nowych warunków światowej konkurencji branż już w regionie istniejących. W ten sposób RSI mogą stać się narzędziem restrukturyzacji w regionach tradycyjnie przemysłowych. 
INSTRUMENTY BUDOWANIA REGIONALNYCH SYSTEMÓW INNOWACJI

Z dokumentów tworzonych przez instytucje zajmujące się realizacją i koordynacją programów RSI można wnioskować, iż najważniejszymi instrumentami budowania regionalnych systemów innowacji, czyli instrumentami polityki intraregionalnej sprzyjającej rozwojowi środowiska proinnowacyjnego są:

- identyfikacja branż i instytucji w regionie, które mogą stać się filarami systemu,

- zwiększanie współpracy zinstytucjonalizowanej i niezinstytucjonalizowanej pomiędzy:

- przedsiębiorstwami, instytucjami otoczenia biznesu i administracją samorządową,

- przedsiębiorstwami i instytucjami otoczenia biznesu,

- przedsiębiorstwami i instytucjami tworzącymi lub transferującymi wiedzę,

- przedsiębiorstwami (dużymi, małymi i średnimi),

- budowa instrumentów „otwierających” system regionalny [FOR-RIS Experiences and ideas 2004].

Te działania powinny znaleźć odzwierciedlenie w procesie tworzenia regionalnych strategii innowacji.

\section{ROLA POSZCZEGÓLNYCH AKTORÓW I ICH KORZYŚCI}

Instytucje tworzące wiedzę, instytucje transferu wiedzy i instytucje otoczenia biznesu powinny w procesie budowania strategii innowacji zidentyfikować potrzeby przedsiębiorstw w regionie i dostosować swoją ofertę do tych potrzeb. Pozwoli to nie tylko na skuteczne funkcjonowanie systemu innowacji w regionie, ale również zapewni tym instytucjom efektywne funkcjonowanie na rynku. Między innymi, uświadomieniu i zrealizowaniu tej potrzeby na poziomie regionalnym służyć ma proces tworzenia regionalnych strategii innowacji.

Administracja samorządowa szczebla regionalnego jest czynnikiem inicjującym i koordynującym proces, nadaje impuls i monitoruje proces powstawania strategii, tak więc ma istotny wpływ na jej kształt ostateczny. Sprawia to, że może odegrać niezwykle pozytywną rolę, zarówno dla strategii, jak i dla dalszego swojego funkcjonowania w regionie, a w szczególności w sektorze przedsiębiorstw, ale również może odegrać rolę negatywną, hamująca, poprzez zdominowanie procesu tworzenia RSI, bez należytego uwzględnienia specyfiki sektora przedsiębiorstw [Szultka i in. 2004]. Na koordynującą rolę samorządu regionalnego składają się również działania związane z przekazywaniem najlepszych doświadczeń pomiędzy regionami europejskimi, które są ważnym elementem całego pomysłu.

Tworzenie RSI może również aktywizować samorząd lokalny na rzecz efektywnej współpracy z sektorem przedsiębiorstw oraz służyć powstawaniu zupełnie nowych instytucji (najczęściej związanych z transferem wiedzy lub finansowaniem procesu tworzenia i pozyskiwania innowacji). Najważniejszą rolę w systemie spełniają przedsiębiorstwa, są one podmiotem opisanych działań, ale równocześnie ich najważniejszym przedmiotem. Kluczowa rola $\mathrm{w}$ regionalnym systemie innowacji przypisywana jest przedsiębiorstwom małym i średnim [Regional Innovation Strategies 2002], jako środowisku powstawania innowacji. W niektórych przypadkach ważną rolę w regionalnym systemie innowacji odegrały duże 
lub wręcz największe przedsiębiorstwa regionu. Ich działania służyły jednak rozwojowi przedsiębiorstw małych i średnich. Na przykład, w holenderskim regionie Limburgia małe i średnie firmy miały możliwość uzyskania voucherów dających prawo do korzystania z laboratoriów badawczych jednej z dwóch największych firm regionu przez okres do trzech dni [Szultka i in. 2004].

W procesie budowania regionalnej strategii innowacji celem jest: identyfikacja MSP najlepiej radzących sobie z wykorzystywaniem społecznych, kulturowych i materialnych zasobów regionu i najlepiej zorganizowanych; identyfikacja potrzeb tych MSP; a także skuteczne zachęcenie ich do współpracy w skali regionu pomiędzy sobą, z administracją oraz instytucjami mogącymi przyczynić się do ich rozwoju. Cechą tego procesu jest więc przełamywanie nieufności przedsiębiorców.

Przedsiębiorstwa są najważniejszymi aktorami regionalnego systemu innowacji, ale również jego najważniejszymi beneficjentami, rozwój przedsiębiorstw wyznacza rozwój pozostałych elementów.

\section{RSI w UE}

Idea budowania planów rozwoju technologicznego na poziomie regionalnym powstała w UE jeszcze w latach 80. XX wieku. Obecnie Unia proponuje kilka specyficznych programów akcji innowacyjnych, które pozwalają regionom rozwijać praktykę innowacji. Zgodnie z zamysłem twórców tych programów, powinny one funkcjonować jako rodzaj laboratoriów, oferując regionom możliwość podjęcia ryzyka i eksperymentowania z najnowocześniejszymi podejściami do trzech dziedzin: gospodarki wiedzy, społeczeństwa informacyjnego i promocji tożsamości regionalnej. Programy te powstają w Unii od 1994 r. Od tego czasu cały czas są ulepszane [Regional Innovation Strategies 2002]. W 1994 roku DG XII ds. Przedsiębiorczości Komisji Europejskiej stworzyła tzw. Programy Innowacyjne, w ich ramach powstawały Regional Innovation and Technology Transfer Strategies (RITTS). Podobny program uruchomiła DG XVI ds. Polityki Regionalnej - Regionalne Strategie Innowacji. Programy RSI+ również finansowane są przez Dyrekcję ds. Polityki Regionalnej i mają na celu wspieranie pomysłów, projektów, które narodziły się podczas konstruowania RSI i RITTS. Obecnie z programu RSI+ skorzystało 25 regionów. Istnieje jeszcze inicjatywa Trans-Regional Innovation Projects (TRIP), na jej podstawie finansowane są projekty opierające się na współpracy regionów, które porównują doświadczenia na temat sposobów wdrażania innowacji w przedsiębiorstwach z kilku regionów. Z programu skorzystało 40 regionów w ramach 11 projektów*. Od 1994 r. tego typu dokumenty opracowało około 100 regionów europejskich.

\section{RSI w Polsce}

W latach 2001-2002 proces budowania RSI zapoczątkowany został również w 16 regionach krajów kandydujących wtedy do UE, w tym pięciu polskich (warmińsko-mazurskie,

\footnotetext{
"www.innovating-regions.org, listopad 2004.
} 
zachodniopomorskie, wielkopolskie, śląskie, opolskie). Były to programy finansowane z V Ramowego Programu Badań i Rozwoju Technicznego UE. W 2003 roku proces tworzenia RSI zapoczątkowano również w pozostałych polskich województwach, finansowany był ze środków KBN i środków urzędów marszałkowskich.

Zgodnie z wytycznymi UE najważniejszymi zasadami procesu budowy regionalnych strategii innowacji są:

- partnerstwo i konsensus publiczno-prywatny (we wszystkich etapach prac),

- nacisk na stronę popytową oraz oddolne podejście przy ich opracowywaniu,

- zorientowanie na działania (powinny zawierać plan, ale również projekty),

- wykorzystywanie wymiaru europejskiego,

- cykliczność [Regional Innovation Strategies 2002].

W procesie wdrażania projektów w ówczesnych krajach kandydujących te założenia metodologiczne zadecydowały, że warunkiem uczestnictwa w projekcie było posiadanie dwóch regionów partnerskich z UE, w tym jednego, który podobną strategię już realizował. W Polsce tego zastrzeżenia nie miały projekty realizowane z funduszy KBN. Ponadto, wydaje się, że tym, co jest szczególnie ważne lub wyróżniające dla polskich RSI było:

- dostosowanie zapisów RSI do zasad wdrażania funduszy strukturalnych, w ten sposób, że realizowanie RSI ułatwi przedsiębiorstwom staranie się o środki UE. Wydaje się, że jest to słuszna strategia w świetle tego, że w wielu analizach przeprowadzonych w polskich województwach przy okazji opracowywania RSI [por. np. Analiza potrzeb innowacyjnych przedsiębiorstw z sektora MŚP $w$ województwie ślaskim oraz Regionalna Strategia Innowacji Województwa Ślaskiego na lata 2003-2013 2003] przedsiębiorstwa wskazywały, że brak środków finansowych jest jedną z najważniejszych przyczyn zaniechania wdrażania innowacji, a z drugiej strony fundusze europejskie będą w najbliższych latach najbardziej obfitym źródłem publicznych pieniędzy dostępnym dla przedsiębiorstw,

- proces budowania RSI był narzędziem określania specyficznych branż dla regionu, lub był równoległy z tym procesem. To znaczy, że ze względu na procesy formowania się w Polsce instytucji regionalnych oraz adaptowania się nowego podziału administracyjnego kraju, budowanie RSI przebiegało równolegle z procesem określania specjalizacji regionu (być może miałby on miejsce również bez realizacji projektu RSI). Nie jest to oczywiście proces „wymyślania” nowych kierunków rozwoju, ale w wielu przypadkach jest to po raz pierwszy, w obecnym administracyjnym kształcie granic, podejmowana decyzja o tym, co powinno, zdaniem władz regionalnych, stać się branżą, dziedziną reklamowaną jako „specjalność” regionu. W regionie podkarpackim, na przykład, władze zadecydowały, że elementem polityki intraregionalnej będzie wspieranie przemysłu lotniczego. Stało się tak, w pewnej mierze pod wpływem powstałej w 2003 r. inicjatywy Stowarzyszenie Grupy Przedsiębiorców Przemysłu Lotniczego „Dolina Lotnicza”. W Programie promocji województwa podkarpackiego na lata 2004-2006 [Program promocji województwa podkarpackiego 2004] uznano, że opracowane w przyszłości logo „Doliny Lotniczej” powinno stać się znakiem graficznym województwa. Strategia ma również odbicie w innych dokumentach strategicznych województwa*, w tym właśnie w pracach nad RSI. Mobilizacja firm branży

* Strategia rozwoju województwa podkarpackiego 2004. 
lotniczej i formułowanie przez urząd marszałkowski regionalnej strategii innowacji przebiegają równocześnie,

- cechą charakterystyczną RSI jest również zwiększanie konwergencji międzyregionalnej [The regions; Rosenfeld 2002] (realizowano je w większości, w regionach celu polityki spójności UE [Szultka i in. 2004: 12]) i w Polsce często kładziono nacisk na ten aspekt zagadnienia.

\section{RSI SILESIA}

[na podstawie: Regionalna Strategia Innowacji Wojewódzka Ślaskiego 2003]

Regionalna strategia innowacji województwa śląskiego jest przykładem budowania regionalnego systemu innowacji w polskim regionie przemysłowym. Formułowanie RSI Silesia rozpoczęto w listopadzie 2001 roku w ramach V Ramowego Programu Badań i Rozwoju Technicznego UE. Strategia nie skupia się na instrumentach restrukturyzacji tradycyjnych gałęzi przemysłu, ale na wspieraniu rozwoju MSP w sektorach, w których już obecnie MSP występują licznie, a także w sektorach, które mogą zostać uznane za nowoczesne, niosące korzyści dla przyszłego rozwoju regionu (,produkcja maszyn biurowych i komputerów, produkcja środków farmaceutycznych, chemikaliów medycznych i środków pochodzenia roślinnego, produkcja statków powietrznych i kosmicznych [sektor lotniczy]"). Tym niemniej zauważa się, że:

w województwie śląskim działalność naukowo-badawcza i rozwojowa koncentruje się wciąż w obszarze tradycyjnych dla regionu sektorach gospodarczych. Prawie $70 \%$ badanych ośrodków $B+R$ jest zaangażowanych w sektory i branże zaliczane do niskiej i średnio niskiej techniki. Stan taki należy uznać za zagrożenie dla sektora $\mathrm{B}+\mathrm{R}$ w województwie śląskim. Jednak nie oznacza to, że trzeba zapomnieć o przeszłości i koncentrować się jedynie na rozbudowie działalności $B+R$ w sektorach średnio wysokiej i wysokiej techniki [...] Należy wyodrębnić mocne strony tradycyjnej działalności sektora $\mathrm{B}+\mathrm{R}$ i wspierać je poprzez specjalizacje w niszach rynkowych nie tylko na poziomie regionalnym, ale również międzynarodowym.

W strategii podkreślone zostało również, że istotnym z punktu widzenia regionalnego systemu innowacji jest „rozwijanie współpracy sektorowej z udziałem MŚP”, w tym - „niektóre tradycyjne sektory przemysłowe będą w dalszym ciagu odgrywać istotną rolę w gospodarce województwa. Sektor energetyki oraz przemysł wydobywczy angażują szereg MŚP. Wokół niektórych z nich powstały już pierwsze sieci”.

Można wnioskować, że niezwykle ważnym narzędziem rozwoju regionalnego systemu innowacji w województwie śląskim ma być wspieranie rozwoju MSP, ale pod wpływem analizy sytuacji gospodarczej regionu zauważono również rolę tradycyjnych przemysłów w tym nowym podejściu do rozwoju gospodarki regionu. Jednak nie ma w strategii wyraźnego podkreślenia potrzeby skupienia się na wykorzystaniu tradycji przemysłów energetycznego czy wydobywczego, są one traktowane jako jeden z równorzędnych elementów. Podkreślone zostało, że przemysł jest najważniejszym środowiskiem powstawania innowacji i województwo śląskie powinno to wykorzystać. 


\section{EFEKTY}

Trudno jeszcze mówić o efektach procesu budowania regionalnych strategii innowacji w Polsce. Po pierwsze, dlatego że czas od rozpoczęcia prac nad dokumentami jest zbyt krótki, a po drugie, dlatego że w niektórych województwach prace jeszcze się nie zakończyły. Ponadto, nawet zakończenie prac nad strategią nie umożliwia wyciągnięcia wniosków, co do efektywności funkcjonowania regionalnego systemu innowacji, a tylko to pozwoli ocenić, czy powzięty przez samorząd regionalny sposób formułowania strategii innowacyjnej w danym regionie był skuteczny.

W dokumentach europejskich można znaleźć próby oceny strategii, które powstawały w regionach państw „starych członków” Unii. Niektóre z nich, z całą pewnością, można odnieść do regionów polskich:

- 100 regionów europejskich uzyskało wsparcie na sformułowanie strategii budowania regionalnego systemu innowacji (pięć regionów polskich uzyskało wsparcie z funduszy unijnych, reszta z polskich),

- w proces budowania regionalnych systemów innowacji i wymiany doświadczeń włączono kraje kandydujące (Bułgaria, Rumunia),

- przeprowadzono liczne analizy ukazujące samorządom regionalnym sytuację przedsiębiorstw i aktywność w dziedzinie badań w regionie. Te badania ukazały kształt infrastruktury wytwarzania i transferu technologii w regionie, $\mathrm{z}$ uwzględnieniem potrzeb MSP (tego typu prace, $\mathrm{z}$ różną skutecznością, przeprowadzone były również w Polsce),

- nakreślono najważniejsze problemy regionu związane z funkcjonowaniem systemu innowacji (doświadczenie firm, niedostosowanie poszczególnych aktorów, brak współpracy pomiędzy sferą nauki, przemysłu i edukacji oraz pomiędzy poszczególnymi polami badawczymi), (podobnie jak przy poprzednim zagadnieniu, z różnym natężeniem i w różny sposób, ale również w Polsce podjęto takie działania) [Blueprints for Foresight Actions in the Regions 2004].

Bez przeprowadzenia szczegółowych empirycznych badań w województwach po upływie kilku lat od rozpoczęcia wdrażania RSI, nie możliwe jest osądzenie, czy pozostałe efekty zauważone przy okazji prac nad pierwszymi RSI w Unii Europejskiej wystąpiły również w Polsce:

- projekty służyły promocji współpracy i tworzenia sieci pomiędzy kluczowymi partnerami regionalnego systemu innowacji. Określiły również role i odpowiedzialność poszczególnych partnerów,

- przeprowadzone analizy i zbudowane sieci były podstawą prac strategicznych, w które włączone zostały aspekty finansowe, komercyjne, szkoleniowe i organizacyjne obok aspektów technicznych,

- promowały myślenie strategiczne na kilku poziomach, np. na poziomie gron przedsiębiorczości. Wspierały tworzenie zgody regionalnej, w niektórych przypadkach na podstawie konsensusu udało się stworzyć długofalowe wizje rozwoju,

- jednym z najważniejszych był rozwój infrastruktury tworzącej innowacje. Programy pilotażowe i usługi wspierające zostały zaplanowane i wdrożone. Rozwój struktur organizacyjnych (instytucji pośredniczących między nauką a przemysłem) był jed- 
nym z najbardziej praktycznych efektów RSI. W wyniku projektów RSI powstał również system monitorowania i ewaluacji instrumentów polityki proinnowacyjnej,

- rozwój myślenia w perspektywie europejskiej. Spostrzeżenie europejskiego kontekstu funkcjonowania regionu i zawarcie nowych umów międzynarodowych [Blueprints for Foresight Actions in the Regions 2004].

Regionalne strategie innowacji są instrumentem budowania konsensusu regionalnego na rzecz rozwoju przedsiębiorczości. Mają stworzyć środowisko powstawania innowacji w regionie i przekształcić je w system sprawnie pozyskujący, wytwarzający i wykorzystujący innowacje. Mają też wyróżnić specyficzne, ważne, dające potencjalne szanse rozwoju branże gospodarki regionalnej. Najważniejszym środkiem finansowania regionalnego systemu innowacji na początku mają być fundusze strukturalne. Regionalne strategie innowacji mają także przygotować przedsiębiorstwa do absorpcji funduszy. W tym sensie mogą stać się one skutecznym narzędziem restrukturyzacji przemysłu, czy szerzej, gospodarki regionalnej, każdego regionu. Jak każde narzędzie stosowane przez administrację zależą jednak silnie od sprawności instytucjonalnej tejże administracji.

\section{Literatura}

Blueprints for Foresight Actions in the Regions. FOR-RIS. Experiences and ideas for developing regional foresight in a RIS/RITTS project context, 2004, European Commission, Bruksela

FOR-RIS Experiences and ideas for developing regional foresight in a RIS/RITTS project context, Blueprints for Foresight Actions in the Regions, 2004, European Commission, Bruksela

Program promocji województwa podkarpackiego na lata 2004-2006, Rzeszowska Agencja Rozwoju Regionalnego S.A., Rzeszów, www.podkarpacie.pl, listopad 2004

Regional Innovation Strategies under the European Regional Development Fund Innovative Actions 2000-2002, 2002, European Commission DG Regional Policy

Regionalna Strategia Innowacji Województwa Ślaskiego na lata 2003-2013, 2003, Sejmik województwa śląskiego, Katowice

Rosenfeld S.A., 2002, Creating Smart Systems. A guide to cluster strategies in less favoured regions. European Union - Regional Innovation Strategies, Regional Technology Strategies, USA, www. europa.eu.int/comm/regional_policy, listopad 2004

Strategia rozwoju województwa podkarpackiego na lata 2000-2006. Aktualizacja na lata 2004-2006, 2004, Rzeszów

Szultka S., Tamowicz P., Mackiewicz M., 2004, Regionalne strategie a systemy innowacji. Najlepsze praktyki. Rekomendacje dla Polski, [w:] Niebieskie Księgi 2004. Rekomendacje Nr 12, Instytut Badań nad Gospodarką Rynkową, Gdańsk

The regions and the new economy. Guidelines for innovative actions co-funded by the European Regional Development Fund 2000-06, Commission communication to the Member States, $\mathrm{COM} / 2001 / 0060 /$ final of $31 / 01 / 01$ 


\section{Regional Innovation Strategies - a factor in Polish industrial space activation}

The main goal of the article is to present the regional innovation strategies in the context of the industrial changes in Poland. The analysis has three parts. The first part introduces the general aims of RIS and their history in Europe, the second concerns the RIS in Poland and one of the Polish RIS in particular - RIS Silesia, and the third part describes the effects of Regional Innovations Strategies.

RIS are the instruments of regional governments to build the regional innovation systems. A regional innovation system is the environment improving the entrepreneurship and innovation. RIS have been known in Europe since the 1980s but in Poland they are a new instrument implemented by the relatively new structures of regional government.

The process of creation and implementation of these documents should be observed by the academics from the beginning, as it may turn out to be one of the most important instruments of the economic policy of the Polish regions. This is because of the financial capacity of the Polish regions and their willingness to follow the West European regions' example. 